\title{
OPEN
}

\section{Author Correction: Validating a breast cancer score in Spanish women. The MCC-Spain study}

Trinidad Dierssen-Sotos, Inés Gómez-Acebo $\mathbb{D}$, Camilo Palazuelos, Pablo FernándezNavarro, Jone M. Altzibar, Carmen González-Donquiles, Eva Ardanaz, Mariona Bustamante, Jessica Alonso-Molero, Carmen Vidal, Juan Bayo-Calero, Adonina Tardón, Dolores Salas, Rafael Marcos-Gragera, Víctor Moreno, Paz Rodriguez-Cundin, Gemma Castaño-Vinyals, María Ederra, Laura Vilorio-Marqués, Pilar Amiano, Beatriz Pérez-Gómez $(\mathbb{D}$, Nuria Aragonés, Manolis Kogevinas, Marina Pollán \& Javier Llorca

Correction to: Scientific Reports https://doi.org/10.1038/s41598-018-20832-0, published online 14 February 2018

The original version of this Article contained a typographical error in the spelling of the author Gemma Castaño-Vinyals, which was incorrectly given as Gemma Castaño Vinyals.

In addition, the Supplementary Information file also contained a typographical error in the spelling of the author Jessica Alonso-Molero, which was incorrectly given as Jessica Alonso.

These errors have now been corrected in the PDF and HTML versions of the Article, and in the accompanying Supplementary Information file.

\begin{abstract}
(c) Open Access This article is licensed under a Creative Commons Attribution 4.0 International License, which permits use, sharing, adaptation, distribution and reproduction in any medium or format, as long as you give appropriate credit to the original author(s) and the source, provide a link to the Creative Commons license, and indicate if changes were made. The images or other third party material in this article are included in the article's Creative Commons license, unless indicated otherwise in a credit line to the material. If material is not included in the article's Creative Commons license and your intended use is not permitted by statutory regulation or exceeds the permitted use, you will need to obtain permission directly from the copyright holder. To view a copy of this license, visit http://creativecommons.org/licenses/by/4.0/.
\end{abstract}

(C) The Author(s) 2020 